\title{
Editorial
}

\section{Is There a Penumbra Surrounding Intracerebral Hemorrhage?}

\author{
A. Gass \\ Neurologische Universitätsklinik, Kantonsspital, Basel, Schweiz
}

Numerous MRI studies have demonstrated that the concept of an MRI-defined area of tissue at risk of infarction in focal cerebral ischemia can provide important additional information to estimate prognosis in early stroke $[1,2]$. This has been shown to be of practical value for patient selection in treatment trials and is used as a diagnostic guidance within institutional protocols for thrombolytic treatment. So it was tempting to explore the situation in a similar fashion in another kind of stroke, when sudden parenchymal hemorrhage can be identified and a prognostic assessment is of major importance. Several systematic studies have used modern MRI technology to address the question whether in severe oligemia there is salvageable tissue, i.e. a penumbra surrounding acute intracerebral hemorrhage [3-5].

The applied techniques have not only been perfusionweighted and diffusion-weighted magnetic resonance imaging, but also positron emission tomography, single photon emission tomography and perfusion computed tomography [6-9]. The most important finding of these studies is that different from ischemic strokes from proximal or distal middle cerebral artery occlusion a penumbra following the territory of arterial branches does usually not exist after intracerebral hemorrhage. The studies that have noted indications of perihemorrhagic hypoperfusion reported a thin rim of $2 \mathrm{~mm}$ to a maximum width of $1 \mathrm{~cm}$. This has led previous authors to conclude that local compression, diaschisis or locally mediated toxic clot components are likely candidates for possible peri- hemorrhagic tissue damage rather than surrounding ischemia.

Pascual et al. [10] now add to this data bank with their experience from dedicated follow-up MRI, which fits previous evidence. Their figures nicely demonstrate two important issues to consider: cortical and subcortical areas appear remarkably normal and wider areas of hypoperfusion as expected in middle cerebral artery obstruction are lacking. The study also shows that perihemorrhagic susceptibility effects make it very difficult to interpret the immediate vicinity of the bleed.

Certainly further studies are needed, in particular in order to explore the mechanisms of worsening in patients that have larger symptomatic bleeds and show clinical deterioration [11]. However, MRI as used in acute stroke imaging has some limitations and new studies should try to overcome present difficulties. CT perfusion provides the highest spatial resolution, which appears advantageous for the analysis of the rim around the hematoma without the problem of susceptibility artifacts due to paramagnetic effects of hemoglobin and its derivatives. Yet MRI is still important in order to identify diffusion-weighted imaging lesions that may indicate the core of the lesion or to show that arterial ischemia may have been the primary pathology before a bleeding occurs. A combination of both techniques should be employed, but optimized logistics and imaging protocols, avoiding the use of susceptibility-sensitive MRI sequences for perfusion-weighted and diffusion-weighted imaging would be ideal.

\section{KARGER \\ Fax +41613061234 E-Mail karger@karger.ch} www.karger.com

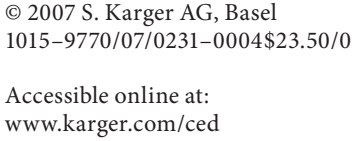

Prof. Dr. Achim Gass

Neurologische Universitätsklinik, Kantonsspital Basel

Petersgraben 4

$\mathrm{CH}-4031$ Basel (Switzerland)

Tel. +41 61265 4386, E-Mail agass@uhbs.ch 


\section{References}

1 Schlaug G, Benfield A, Baird AE, Siewert B, Lovblad KO, Parker RA, Edelman RR, Warach S: The ischemic penumbra: operationally defined by diffusion and perfusion MRI. Neurology 1999;53:1528-1537.

2 Rother J, Schellinger PD, Gass A, Siebler M, Villringer A, Fiebach JB, Fiehler J, Jansen O, Kucinski T, Schoder V, Szabo K, Junge-Hulsing GJ, Hennerici M, Zeumer H, Sartor K, Weiller C, Hacke W: Effect of intravenous thrombolysis on MRI parameters and functional outcome in acute stroke $<6$ hours. Stroke 2002;33:2438-2445.

3 Kidwell CS, Saver JL, Mattiello J, Warach S, Liebeskind DS, Starkman S, Vespa PM, Villablanca JP, Martin NA, Frazee J, Alger JR: Diffusion-perfusion MR evaluation of perihematomal injury in hyperacute intracerebral hemorrhage. Neurology 2001;57: 1611-1617.
4 Schellinger PD, Fiebach JB, Hoffmann K, Becker K, Orakcioglu B, Kollmar R, Juttler E, Schramm P, Schwab S, Sartor K, Hacke W: Stroke MRI in intracerebral hemorrhage: is there a perihemorrhagic penumbra? Stroke 2003;34:1674-1679.

5 Zhao X, Wang Y, Wang C, Li S, Wang Y, Yang Z: Quantitative evaluation for secondary injury to perihematoma of hypertensive cerebral hemorrhage by functional MR and correlation analysis with ischemic factors. Neurol Res 2006;28:66-70.

6 Zazulia AR, Diringer MN, Videen TO, Adams RE, Yundt K, Aiyagari V, Grubb RL Jr, Powers WJ: Hypoperfusion without ischemia surrounding acute intracerebral hemorrhage. J Cereb Blood Flow Metab 2001;21: 804-810.

7 Fainardi E, Borrelli M, Saletti A, Schivalocchi R, Russo M, Azzini C, Cavallo C, Ceruti S, Chieregato A, Tamarozzi R: Assessment of acute spontaneous intracerebral hematoma by CT perfusion imaging. J Neuroradiol 2005;32:333-336.
8 Rosand J, Eskey C, Chang Y, Gonzalez RG, Greenberg SM, Koroshetz WJ: Dynamic single-section CT demonstrates reduced cerebral blood flow in acute intracerebral hemorrhage. Cerebrovasc Dis 2002;14:214-220.

9 Koenig M, Kraus M, Theek C, Klotz E, Gehlen W, Heuser L: Quantitative assessment of the ischemic brain by means of perfusionrelated parameters derived from perfusion CT. Stroke 2001;32:431-437.

10 Pascual AM, Lopez-Mut JV, Benlloch J, Chamarro R, Soler J, Lainez MJA: Perfusionweighted magnetic resonance imaging in acute intracerebral hemorrhage at baseline and during the 1st and 2nd week: a longitudinal study. Cerebrovasc Dis 2007;23:6-13.

11 Warach S: Editorial comment: Is there a perihematomal ischemic penumbra? More questions and an overlooked clue. Stroke 2003;34:1680. 